\title{
KUNCI SUKSES PENANAMAN NILAI-NILAI PENDIDIKAN ISLAM TERHADAP PESERTA DIDIK
}

Kamus

STAIN Majene

Email: kamusmustamin@stainmajene.ac.id

\begin{abstract}
Abstrak
Penelitian ini bertujuan untuk menggambarkan kunci sukses optimalisasi penanaman nilai-nilai pendidikan Islam pada implementasi Kurikulum 2013. Penelitian ini merupakan jenis penelitian lapangan bersifat kualitatif deskriftif. Hasil penelitian menunjukkan bahwa; pembiasaan dan keteladanan didasarkan pada penanaman afektif berupa sikap spiritual dan sosial. Sikap spiritual berupa pembiasaan ibadah. Pembiasaan tersebut menumbuhkan nilai ketundukan kepada Allah, jiwa dan raga senantiasa dekat kepada Allah. Pembiasaan dan keteladanan syukur. Pembiasaan syukur menumbuhkan sikap kerendahan hati kepada Allah, harapan, dan semangat ibadah. Sikap sosial berupa sikap jujur. Pembiasaan tersebut menumbuhkan nilai komitmen, keberanian dan tangung jawab. Sikap santun, Pembiasaan tersebut menumbuhkan karakter komunikatif dan cinta damai.
\end{abstract}

\section{Kata Kunci; Kunci sukses, nilai-nilai pendidikan Islam, kualitatif deskriktif}

\section{A. PENDAHULUAN}

Penanaman nilai-nilai pendidikan Islam dapat sukses terwujud secara efektif dan efisien bila penyelenggara pendidikan mengimplementasikan kunci-kunci kesuksesan. Pada Kurikulum 2013 mampu bermanfaat dan berkualitas bila dirumuskan dalam indikator strategis bagi manusia terdidik, seperti beriman, bertakwa, berakhlak mulia, sehat, berilmu, cakap, kreatif, mandiri, dan menjadi warga negara yang demokratis serta bertanggung jawab. ${ }^{1}$ Pendidikan nilai-nilai kehidupan tidak dapat berlangsung baik jika tidak ditunjang keteladanan pendidik dan praktis sosial yang kontinyu dan konsisten dalam kehidupan sosial. ${ }^{2}$

Allah 畄 berfirman dalam QS al-Ahzāb/33: 21

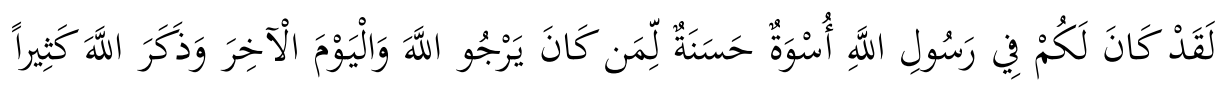
2014), h. 34.

${ }^{1}$ Loeloek Endang Poerwati, Sofan Amri, Panduan Memahami Kurikulum 2013 (Cet. I; Prestasi Pustaka:

${ }^{2}$ Qiqi Yuliati Zakiyah dan A. Rusdiana, Pendidikan Nilai, Kajian Teori dan Praktik di Sekolah, h. 82-83. 
Terjemahnya:

Sesungguhnya telah ada pada (diri) Rasulullah itu suri teladan yang baik bagimu (yaitu) bagi orang yang mengharap (rahmat) Allah dan (kedatangan) hari kiamat dan dia banyak menyebut Allah. ${ }^{3}$

Di samping itu, tanpa keteladanan kepada siswa semua hanya teori, mereka seperti gudang ilmu yang berjalan, tetapi tidak pernah merealisasikan dalam kehidupan. Dengan keteladanan, pendidikan akan membekas dalam kehidupan siswa. Penanaman nilai-nilai kehidupan kepada siswa membutuhkan keteladanan dari guru, orang tua, dan masyarakat. Penanaman nilai-nilai tersebut tidak hanya berlangsung di sekolah, tetapi juga di lingkungan keluarga dan masyarakat. ${ }^{4}$

M.D. Dahlan dalam Hery Noer Aly memandang bahwa pembiasaan merupakan proses penanaman kebiasaan. Kebiasaan (habit) ialah cara-cara bertindak yang persistent, uniform, dan hampir-hampir otomatis (hampir-hampir tidak disadari oleh pelakunya). ${ }^{5}$ Menanamkan kebiasaan itu sulit dan kadang-kadang memerlukan waktu yang lama. Kesulitan itu disebabkan pada mulanya seseorang atau anak belum mengetahui secara praktis sesuatu yang hendak dibiasakannya. Apalagi kalau yang dibiasakan itu dirasa kurang menyenangkan. Oleh sebab itu, menanamkan kebiasaan diperlukan pengawasan. Bahkan dalam hal ini pendidik dapat menggunakan motivasi dengan kata-kata baik, bisa memberi hadiah, hingga menggunakan hukuman apabila dipandang perlu dalam meluruskan penyimpangan. ${ }^{6}$

SMA Negeri 10 Bulukumba dalam mencapai visinya, maka salah satu misi utamanya ialah "Menumbuhkan semangat beribadah secara intensif agar warga sekolah hidup dalam naungan nilai-nilai agama".7 Bila menganalisis Kurikulum 2013 secara cermat peneliti menemukan adanya nilai-nilai pendidikan Islam demikian pula pada Visi Misi SMA 10 Bulukumba terdapat konsep keagamaan. Oleh karena itu, peneliti tertarik untuk meneliti kunci sukses optimalisasi penanaman nilai-nilai pendidikan Islam pada implementasi Kurikulum 2013 di SMA Negeri 10 Bulukumba sebagai media mencapai Visi Misinya.

\section{B. PEMBAHASAN}

\footnotetext{
${ }^{3}$ Kementrian Agama RI, Al-Qura'n dan Terjemahnya (Cet. I; Jakarta: Syaamil Quran, 2015), h. 420.

${ }^{4}$ Qiqi Yuliati Zakiyah dan A. Rusdiana, Pendidikan Nilai, Kajian Teori dan Praktik di Sekolah, h. 83.

${ }^{5}$ Hery Noer Aly, Ilmu Pendidikan Islam (Cet. II; Jakarta: PT Logos Wacana Ilmu, 1999 M/1420 H), h. 44.

${ }^{6}$ Abdullāh 'Ulwān, Tarbiyyah al-Aulād fì al-Islām, Juz 2 (Beirut: Dār al-Salām, 1978), h. 682.

${ }^{7}$ http://www.sman10bulukumba.sch.id/profile/visi-dan-misi (29 November 2016)
} 
Ada dua kunci sukses yang dapat dilakukan dalam penanaman nilai-nilai pendidikan Islam yaitu keteladanan dan pembiasaan.

\section{Keteladanan}

Keteladanan adalah wasilah yang paling dahsyat dari seluruh metode untuk meraih kesuksesan dalam pendidikan Islam. ${ }^{8}$ Penanaman nilai-nilai pendidikan Islam tidak dapat berlangsung baik jika tidak ditunjang keteladanan pendidik dan praktis sosial yang kontinyu dan konsisten dalam kehidupan sosial. Untuk itulah Allah Subḥāna Wata'àlā mengutus Nabi Muhammad Sallallāhu 'Alaihi Wasallam. Allah Subhāna Wata'ālā berfirman dalam Q.S. alAhzāb/33: 21.

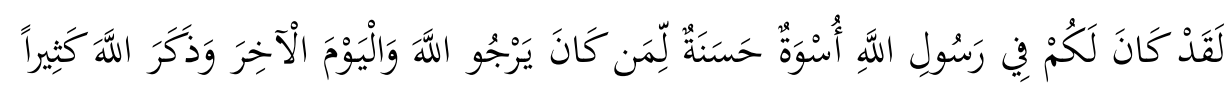

Terjemahnya:

Sesungguhnya telah ada pada (diri) Rasulullah itu suri teladan yang baik bagimu (yaitu) bagi orang yang mengharap (rahmat) Allah dan (kedatangan) hari kiamat dan dia banyak menyebut Allah. ${ }^{9}$

Pada diri beliau diletakkan profil lengkap dari kurikulum Islam. Sebuah profil yang hidup abadi sepanjang sejarah. ${ }^{10}$ Demikian pula dalam Hadis Nabi Sallallāhu 'Alaihi Wasallam memperlihatkan tata cara pelaksanaan shalat lalu bersabda:

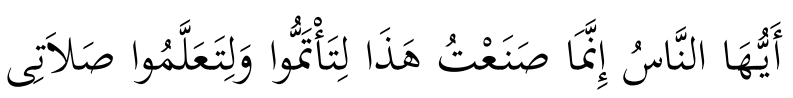

Artinya:

Wahai sekalian manusia sesungguhnya aku melakukan ini agar kalian mengikutiku, dan agar kamu belajar dari shalatku. ${ }^{11}$

Di samping itu, tanpa keteladanan kepada siswa semua hanya teori. Mereka seperti gudang ilmu yang berjalan, tetapi tidak pernah merealisasikan dalam kehidupan. Dengan keteladanan, pendidikan akan membekas dalam kehidupan siswa.

\footnotetext{
${ }^{8}$ Muhammad Quțub, Manhaj al-Tarbiyyah al-Islāmiyyah Juz 1 (Cet. XIV; Al-Qāhirah; Dār al-Syurūq, 1993 M/ 1414 H), h. 180.

${ }^{9}$ Kementrian Agama RI, Al-Qura'n dan Terjemahnya (Cet. I; Jakarta: Syaamil Quran, 2015), h. 420.

${ }^{10}$ Ahmad Farid, Pendidikan Berbasis Metode Ahlus Sunnah wa al-Jama'ah (Cet. I; Surabaya: Pustaka Elba, 2011), h. 427.

${ }^{11}$ Muhammad bin Ismā̄̄l al-Bukhāri, Al-Jāmi' al-Șah̄ịh al-Mukhtașar, Juz 4 (Beirut: Dār ibnu Kas̀̄̄r, 1407 H/ 1987 M), h. 36. Dikutip dalam Abū al-Husain Muslim, Al-Jāmi' al-Ṣaḥ̄ḥ al-Musammā Ṡahīh Muslim, , Juz 2 (Beirut: Dār al-Jail Beirut), h. 74.
} 
Penanaman nilai-nilai pendidikan Islam kepada siswa membutuhkan keteladanan dari guru, orang tua, dan masyarakat. Penanaman nilai-nilai tersebut tidak hanya berlangsung di sekolah, tetapi juga di lingkungan keluarga dan masyarakat. ${ }^{12}$

\section{Pembiasaan}

M.D. Dahlan dalam Hery Noer Aly memandang bahwa pembiasaan merupakan proses penanaman kebiasaan. Kebiasaan (habit) ialah cara-cara bertindak yang persistent, uniform, dan hampir-hampir otomatis (hampir-hampir tidak disadari oleh pelakunya). ${ }^{13}$

Metode pembiasaan banyak ditunjukkan oleh ayat-ayat al-Quran, diantaranya Q.S. AlNūr/24: 58-59.

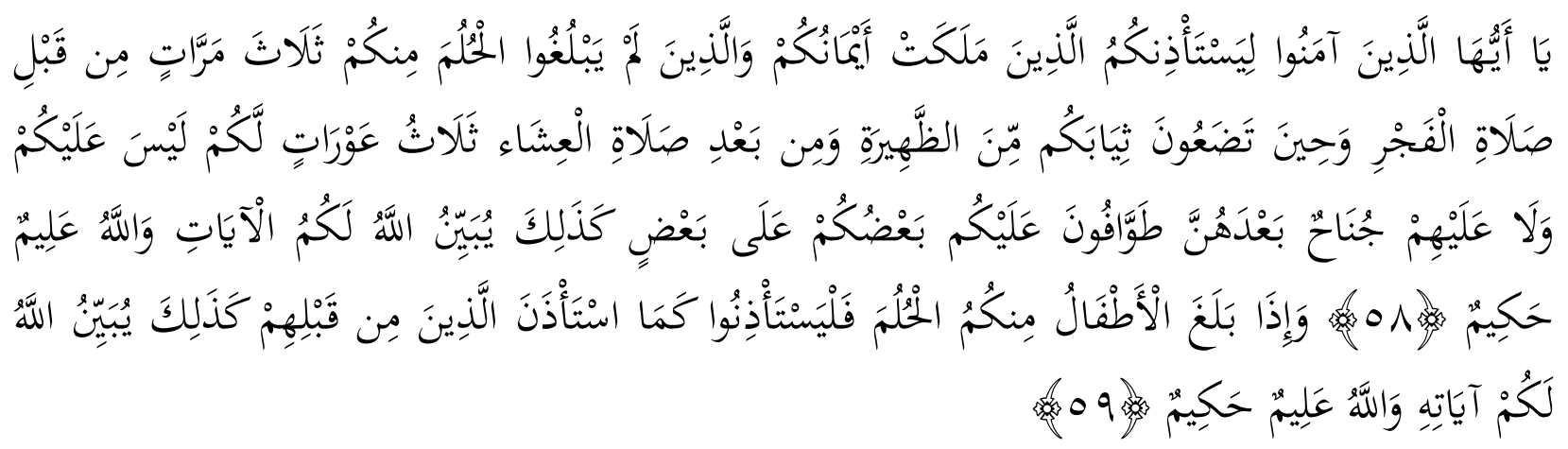

Terjemahnya:

Hai orang-orang yang beriman, hendaklah budak-budak (lelaki dan wanita) yang kamu miliki, dan orang-orang yang belum balig di antara kamu, meminta izin kepada kamu tiga kali (dalam satu hari) yaitu: sebelum sembahyang subuh, ketika kamu menanggalkan pakaian (luar) mu di tengah hari dan sesudah sembahyang Isya'. (Itulah) tiga 'aurat bagi kamu. Tidak ada dosa atasmu dan tidak (pula) atas mereka selain dari (tiga waktu) itu. Mereka melayani kamu, sebahagian kamu (ada keperluan) kepada sebahagian (yang lain). Demikianlah Allah menjelaskan ayat-ayat bagi kamu. Dan Allah Maha Mengetahui lagi Maha Bijaksana. Dan apabila anak-anakmu telah sampai umur balig, maka hendaklah mereka meminta izin, seperti orang-orang yang sebelum mereka meminta izin. Demikianlah Allah menjelaskan ayat-ayat-Nya. Dan Allah Maha Mengetahui lagi Maha Bijaksana. ${ }^{14}$

${ }^{12}$ Qiqi Yuliati Zakiyah dan A. Rusdiana, Pendidikan Nilai, Kajian Teori dan Praktik di Sekolah, h. 83.

${ }^{13}$ Hery Noer Aly, Ilmu Pendidikan Islam (Cet. II; Jakarta: PT Logos Wacana Ilmu, 1999 M/1420 H), h. 44.

\footnotetext{
${ }^{14}$ Kementrian Agama RI, Al-Qura'n dan Terjemahnya (Cet. I; Jakarta: Syaamil Quran, 2015), h. 420.
} 
Menafsirkan ayat tersebut al-Ṣābūnī menyatakan bahwa pada dasarnya perintah tersebut ditujukan kepada anak kecil yang belum balig namun yang dimaksudkan adalah orang dewasa. Allah memerintahkan kepada para majikan agar membimbing budaknya demikian pula orang tua kepada anaknya agar terbiasa minta izin sebelum memasuki mereka. ${ }^{15}$

Adapun hadīis Nabi yang berkenaan dengan pembiasaan dalam pendidikan adalah

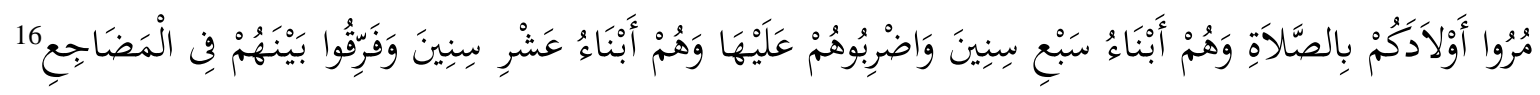

Artinya:

Perintahkanlah anak-anak kalian untuk mendirikan shalat ketika mereka berusia tujuh tahun; dan pukullah mereka apabila meninggalkannya pada usia sepuluh tahun, dan pisahkanlah tempat tidur mereka

Hadīis tersebut menerangkan bahwa perintah ini ditujukan kepada para wali, bukan kepada anak-anak. Para wali diperintahkan agar mengajarkan tata cara shalat kepada anakanaknya ketika berumur tujuh tahun, lalu menyuruh mereka melaksanakannya sesuai dengan pengajaran itu. Hal ini dimaksudkan agar mereka terbiasa dan merasa senang melaksanakan shalat. Setelah berusia sepuluh tahun, hendaknya para wali memukul mereka, karena mereka telah balig atau mendekati balig. Pada umur sepuluh tahun itu pula, para wali memisahkan tempat tidur anak-anak antara satu dengan lainnya. Pemisahan ini dimaksudkan agar untuk menghindarkan gejolak syahwat, meskipun mereka bersaudara. ${ }^{17}$

Menanamkan kebiasaan itu sulit dan kadang-kadang memerlukan waktu yang lama. Kesulitan itu disebabkan pada mulanya seseorang atau anak belum mengetahui secara praktis sesuatu yang hendak dibiasakannya. Apalagi kalau yang dibiasakan itu dirasa kurang menyenangkan. Oleh sebab itu, menanamkan kebiasaan diperlukan pengawasan. Bahkan dalam hal ini pendidik dapat menggunakan motivasi dengan kata-kata baik, bisa memberi hadiah, hingga menggunakan hukuman apabila dipandang perlu dalam meluruskan penyimpangan. ${ }^{18}$

Pembiasaan hendaknya disertai dengan usaha membangkitkan kesadaran atau pengertian terus menerus akan maksud dari tingkah laku yang dibiasakan. Sebab, pembiasaan digunakan

\footnotetext{
${ }^{15}$ Muhammad 'Alī al-Ṣābūn̄̄, Rawā 'i' al-Bayān : Tafsīr Āyāt al-Ahkām al-Qurān Juz 2, (Cet. III; Beirut: Muassasah Manāhil al-'Irfān, 1981M/1401H), h. 210.

${ }^{16}$ Sulaimān Abū Dāwud, Sunan Ab̄̄ Dāwud, Juz 2 (Mesir: Mauqi’ Wizārah al-Auqāf al-Mis̀riyyah), h. 167.

${ }^{17}$ Abū 'Abdi al-Raḥmān Syarf al-Haq, 'Aun al-Ma'būd Syarḥ Sunan Abī Dāwūd, Juz 2 (Saudi; Bait alAfkār al-Dauliyyah, 2013), h. 247.

${ }^{18}$ Abdullāh 'Ulwān, Tarbiyyah al-Aulād fì al-Islām, Juz 2 (Beirut: Dār al-Salām, 1978), h. 682.
} 
bukan untuk memakasa peserta didik agar peserta didik melakukan sesuatu secara otomatis seperti layaknya robot, melainkan agar ia dapat melaksanakan segala kebaikan dengan mudah tanpa merasa susah atau berat hati. ${ }^{19}$

\section{Keteladanan dan Pembiasaan Penanaman Nilai-nilai Pendidikan Islam di SMA Negeri 10}

\section{Bulukumba}

SMA Negeri 10 Bulukumba dalam melaksanakan kegiatan pendidikan senantiasa mendasarkan pada visi dan misi sekolah, yaitu "Menjadikan warga SMA Negeri 10 Bulukumba unggul dalam prestasi, terampil dalam berkarya, berwawasan lingkungan, berlandaskan iman dan taqwa", ${ }^{20}$ dan misi yang mendukung adalah "Menumbuhkan semangat beribadah secara intensif agar warga sekolah hidup dalam naungan nilai-nilai agama". ${ }^{21}$ Berdasarakan amanah Kurikulum 2013 ada tiga nilai capaian yaitu afektif, kognitif dan psikomotorik, nilai afektif terdiri dari sikap spiritual dan sikap sosial. Sikap spiritual dan sosial telah ditetapkan oleh Dinas Pendidikan, adapun sikap spiritual untuk tahun pelajaran 2016/2017 adalah ibadah, do'a, syukur, sementara sikap sosial yaitu jujur, disiplin, tanggung jawab, santun atau sopan. ${ }^{22}$

a. Pembiasaan ibadah

Para peserta didik telah dibiasakan sejak awal menginjakkan kakinya di SMA Negeri 10 Bulukumba ini pada kegiatan PLS (Pengenalan Lingkungan Sekolah) untuk salat berjama'ah baik laki-laki maupun perempuan, dengan harapan seperti itulah yang semestinya nanti dilakukan ketika bersekolah. ${ }^{23}$ Pembiasaan adalah salah satu kunci yang diimplementasikan oleh para pembina SMA Negeri 10 bulukumba untuk menggapai karakter religius bagi para peserta didik. Dalam observasi peneliti menemukan pesan moral

Guru Pendidikan Agama Islam dalam wawancara peneliti temukan bahwa: Diantara bentuk ibadah yang ditumbuhkan dan ditanamkan adalah kewajiban salat lima waktu terkhusus salat zuhur berjama'ah di sekolah, salat asar bila ada kegiatan ekstrakurikuler di sore hari, salat jum'at bagi laki-laki yang digilir sesuai tingkatan, salat rawatib, salat duha, do'a sebelum dan setelah belajar, dzikir pada setiap saat, membaca al-Qur'an yang telah dilegalkan dalam bentuk

${ }^{19}$ Muhammad Quțub, Manhaj al-Tarbiyyah al-Islāmiyyah (Sistem Pendidikan Islam) terj. Salman Harun (Bandung; Al-Maarif, 1984), h. 244.

${ }^{20} \mathrm{http}: / /$ www.sman10bulukumba.sch.id/profile/visi-dan-misi (29 November 2016)

${ }^{21}$ http://www.sman10bulukumba.sch.id/profile/visi-dan-misi (29 November 2016)

${ }^{22}$ Hamsa, S.Pd., M.Pd, Wakil Kepala Sekolah Bagian Kurikulum, Wawancara, Bontobangun 15 Juni 2017.

${ }^{23}$ Drs. Muslim, Wakil Kepala Sekolah Bagian Kesiswaan, Wawancara, Bontobangun 04 Juli 2017. 
ekstrakurikuler keagaamaan. ${ }^{24}$ Memberi salam kepada teman yang ditemui terutama guru, ketika mau memulai pelajaran dan mengakhirinya sebagai bentuk penghormatan kepada bapak/ ibu guru, zakat dan puasa wajib bila bulan Ramadhan, anjuran puasa senin dan kamis, puasa syawal, puasa arafah, puasa muharram dan lain-lain. ${ }^{25}$

Selama masa penelitian pada praktik salat zuhur berjamaah di SMA Negeri 10 Bulukumba peneliti dapat merasakan betapa indahnya salat zuhur bersama kepala sekolah dan para wakil kepala sekolah, tenaga pendidik dan tenaga kependidikan serta para peserta didik. Nilai-nilai pendidikan Islam peneliti temukan dalam salat berjamaah tersebut diataranya adalah ketundukan, kepatuhan, serta pengagungan terhadap perintah Allah Subhāna Wata'ālā dan rasulNya Nabi Muhammad Șallallāhu 'Alaihi Wasallam karena sekalipun dalam kesibukan melakukan aktivitas penelitian perintah Allah Subḥ̂̄na Wata'ālā dan sunnah nabi untuk segera menunaikan salat dapat dilaksanakan. Nilai pendidikan Islam yang juga peneliti rasakan adalah menampakkan syiar Allah, indahnya berjalan menuju rumah Allah sebagai bentuk mujāhadah (kesungguhan/ perjuangan) menepis rasa malas. Nilai kompetititf ketika berlomba meraih pahala yang paling utama, nilai persaudaraan kasih sayang dan persamaan, tak ada perbedaan antara kepala sekolah dan para wakilnya, para guru dan peserta didiknya melainkan keihlasan dan ketakwaannya kepada Allah yang Maha Esa ketika sama-sama berdiri, rukuk, sujud di depan kemahabesaran Allah. Dan nilai membiasakan diri berdisiplin, dimana pada setiap hadir waktu salat, telah terprogram untuk mengahadirkan diri di masjid. Nilai pendidikan Islam dari salat duha yang peneliti dapatkan saat bersama para peserta didik adalah: tidak larut dalam aktifitas dunia, senantiasa mengingat Allah, memupuk kesadaran bahwa mencari rezeki bukan mengandalkan energi saja tapi dari Allah, menenagkan hati, karena dilaksanakan pada saat beraktivitas yang mungkin sedang kalut dalam urusan dunia.

Selama penelitian hasil observasi menunjukkan bahwa terdapat keteladanan dari kepala sekolah, wakil kepala sekolah bagian kurikulum, wakil kepala sekolah bagian kesiswaan, wakil kepala sekolah bagian sarana dan pra sarana. Demikian pula guru-guru Pendidikan Agama Islam, dan guru-guru mata pelajaran umum. Kepala sekolahpun sering kali mengingatkan visi “Iman' dan "Takwa" dan untuk menggapai hal tersebut dibutuhkan keteladanan dari setiap pendidik di

\footnotetext{
${ }^{24}$ Rosnaeni, S.Pd.I, Guru PAI SMA Negeri 10 Bulukumba, wawancara, Bontobangun 08 Juni 2017.

${ }^{25}$ Abdul Syahid Syam, S.Pd.I, Guru PAI SMA Negeri 10 Bulukumba, wawancara, Pangalloang 15 Juli 2017.
} 
sekolah untuk menumbuhkan semangat beribadah sebagaimana yang peneliti dengar secara langsung ketika rapat evaluasi sekolah pada tanggal 27 Juni 2017.

Keempat peserta didik yang diwawancarai mengemukakan bahwa para guru khususnya para guru Pendidikan Agama Islam, Kepala sekolah, Wakasek Bagian Kurikulum, Wakasek Bagian Kesiswaan, Wakasek Bagian Sarana dan Prasarana senantiasa memberikan keteladanan dan mengajak mereka ke masjid tiap waktu zuhur tiba. Gita Safirah dalam wawancara mengakui bahwa tiap menjelang zuhur datang Bapak Awaluddin Aziz, S.Pd. ke tiap kelas untuk mengajak para peserta didik ke masjid, meski saya sendiri jarang melakukan salat zuhur di sekolah berhubung karena rumah dekat, namun bila telah sampai di rumah segera melaksanakan salat zuhur karena waktu zuhur sekitar satu jam lebih. ${ }^{26}$ A. Nurul Fatimah juga sering mendapati Bapak Awaluddin Azis, S.Pd mengajak para peserta didik ke masjid tiap waktu zuhur dan salat asar di masjid bila ada kegiatan di sore hari. ${ }^{27}$ Ihsan menuturkan bahwa setiap zuhur saya dan teman-teman ke masjid maka kami mendapati guru agama kami jadi imam salat, ikut di belakangnya para guru dan peserta didik. ${ }^{28}$ Demikian pula yang diungkapkan oleh A. Arya Putra bahwa guru PAI dan Bapak Drs. Muslim sebagai guru Bahasa Inggris sekaligus Wakasek bagian kesiswaan senantiasa mengajak para peserta didik untuk ke masjid, bahkan guru PAI menugaskannya dalam bentuk daftar hadir salat untuk mencatat setiap teman kelasnya yang salat berjama'ah di masjid sekolah. ${ }^{29}$ Ihsan menuturkan bahwa setiap zuhur saya dan teman-teman ke masjid maka kami mendapati guru agama kami jadi imam salat, ikut di belakangnya para guru dan peserta didik. ${ }^{30}$

Dari wawancara para peserta didik peneliti menemukan bahwa nilai pendidikan Islam yang dirasakan dalam pembiasaan praktik salat berjamaah paling tidak ada tiga item; yaitu kebersamaan, ketenangan, dan kekeluargaan.

Observasi peneliti menemukan terpasang sebuah pesan moral bagi para tenaga pendidik di ruang guru untuk senantiasa menjadi teladan bagi para peserta didiknya dengan Pesan Moral

${ }^{26}$ Gita Safirah, Peserta Didik SMA Negeri 10 Bulukumba (kelas XI MIPA 1), Wawancara, Bontobangun 22 Mei 2017.

${ }^{27}$ A. Nurul Fatimah, Peserta Didik Kelas X IPS 4 SMA Negeri 10 Bulukumba, Wawancara, Bontobangun 23 Mei 2017.

${ }^{28}$ Ihsan Syawal Rahmat, Peserta Didik Kelas X MIPA 1 SMA Negeri 10 Bulukumba, Wawancara, Bontobangun 29 Mei 2017.

${ }^{29}$ A. Arya Putra, Peserta Didik Kelas XI IPS 3 SMA Negeri 10 Bulukumba, Wawancara, Bontobangun 22 Mei 2017.

${ }^{30}$ Ihsan Syawal Rahmat, Peserta Didik Kelas X MIPA 1 SMA Negeri 10 Bulukumba, Wawancara, Bontobangun 29 Mei 2017. 
“Guruku adalah Teladanku”. Observasi peneliti menemukan guru PAI, guru Bahasa Inggris, guru Bahasa Indonesia, Guru Fisika, guru Biologi, Guru Matematika, guru PKN, guru Geografi, guru seni, guru kewirausahaan, guru ekonomi, guru Kimia, guru Bahasa Jerman, guru Antropologi, kepala sekolah dan para wakil kepala sekolahnya, dan guru-guru lainnya serta Guru BK, pegawai perpustakaan, staft tata usaha dan satpam.

Orang tua peserta didik $\mathrm{Hj}$. A. Diana dalam wawancara peneliti temukan adanya perhatian besar terhadap nilai-nilai pendidikan Islam terhadap putranya A. Arya sejak kecil dibiasakan ibadah dengan menentukan tempat ibadah di dalam rumahnya, membangunkan salat subuh, memastikan anaknya telah salat di masjid sekolah setiap pulang ke rumah, mengajarkan dan membiasakan membaca al-Qur'an sampai usia SMA. ${ }^{31}$ Hal inilah yang menjadi salah satu faktor penunjang bagi pihak sekolah dalam menumbuhkan nilai-nilai pendidikan Islam pada peserta didik karena keluarga yang merupakan madrsah al-ūla (sekolah pertama) telah menanamkan nilai-nilai pendidikan Islam, tugas sekolah selanjutnya adalah menumbuhkan dan mengembangkan nilai-nilai tersebut.

Bapak Abdul Syahid Syam memberi contoh bahwa bagi peserta didik SMA masih perlu diajar salat dengan baik dari awal, karena sebagian guru PAI juga ketika menguji praktik ibadah bagi kelas XII mendapati ada diantara mereka yang belum mampu mempraktikkan tata cara wudu yang benar. ${ }^{32}$

Untuk menambah wawasan keagamaan kepada para peserta didik, secara rutin diadakan kegiatan ekstrakurikuler yang dikemas dalam kegiatan permbinaan ibadah remaja, tarbiyah atau Baca Tulis al-Qur'an, para pembina dan pemateri adalah Guru PAI dan beberapa tokoh ahli yang diundang untuk pelaksanaan kegiatan tersebut. Tausiyah Jumat juga diadakan pada setiap jumat pekan keempat untuk menambah wawasan para peserta didik di lapangan upacara SMA Negeri 10 Bulukumba, dengan mengundang para penceramah. Pada bulan ramadan setiap tahunnya pembinaan kerohanian juga digalakkan dengan mewajibkan puasa ramadan, dan memberi taushiyah ramadan sekaligus buka puasa bersama, kegiatan ini telah menjadi tradisi sebagai ajang untuk menyambung silaturahmi diantara para guru dan peserta didik sebelum mengisi waktu libur menjelang hari raya Idul Fitri, tidak tanggung-tanggung biaya yang dikeluarkan mencapai

\footnotetext{
${ }^{31}$ Hj. A. Diana, Orang Tua A. Arya Putra Peserta Didik SMA Negeri 10 Bulukumba, Wawancara, Bontobangun 06 Juli 2017.

${ }^{32}$ Abdul Syahid Syam, S.Pd.I, Guru PAI SMA Negeri 10 Bulukumba, wawancara, Pangalloang 15 Juli 2017.
} 
tujuh juta rupiah utnuk kegiatan yang agung ini, dengan menyiapkan menu menarik seperti makanan khas Bugis Makassar konro, Ikan bakar, udang goreng, sayur cap cay, kue-kue, es buah, kurma dan sebagainya.

Kebiasaan ibadah yang ditumbuhkembangkan di SMA Negeri 10 Bulukumba dapat peneliti klasifikasikan pada tabel berikut ini:

Tabel 0.1 Klasifikasi Bentuk Ibadah

\begin{tabular}{|c|c|c|c|}
\hline No & Jenis Ibadah & Tempat/ Waktu Pelaksanaan & Nilai Pend. Islam \\
\hline 1 & $\begin{array}{l}\text { Salat zuhur/ } \\
\text { asar }\end{array}$ & Masjid Sekolah & $\begin{array}{l}\text { a. Kepatuhan } \\
\text { b. Kebersamaan } \\
\text { c. Persaudaraan } \\
\text { d. Kekeluargaan } \\
\text { e. Kompetisi } \\
\text { f. Mujahadah } \\
\text { g. Syiar }\end{array}$ \\
\hline 2 & Salat Duha & Masjid Sekolah & $\begin{array}{l}\text { a. Kebangkitan } \\
\text { b. Keseimbangan doa \& Ikhtiar }\end{array}$ \\
\hline 3 & Salat Jumat & Masjid Sekolah & $\begin{array}{l}\text { a. Persatuan } \\
\text { b. Kebersamaan } \\
\text { c. Silaturahmi } \\
\text { d. Penambahan ilmu dan wawasan } \\
\text { e. Mendengar petuah }\end{array}$ \\
\hline 4 & $\begin{array}{l}\text { Baca } \\
\text { Tulis } \\
\text { al-Quran }\end{array}$ & Masjid sekolah \& Kelas & $\begin{array}{l}\text { a. Nilai gemar membaca } \\
\text { b. Ketenangan } \\
\text { c. Penyejuk hati } \\
\text { d. Penghilang kegalauan } \\
\text { e. Sarana taqarrub }\end{array}$ \\
\hline 5 & Zikir & Masjid Sekolah \& setiap tempat & $\begin{array}{l}\text { a. Ketenangan } \\
\text { b. Terpaut dengan Allah } \\
\text { c. Membiasakan lisan berkata baik } \\
\text { d. Memenuhi setiap waktu dalam } \\
\text { kebaikan }\end{array}$ \\
\hline
\end{tabular}




\begin{tabular}{|c|c|c|c|}
\hline 6 & Do’a & Kelas sebelum \& sesudah belajar & \begin{tabular}{l} 
a. Ketergantungan kepada Allah\} $\\
{\text { b. Senantiasa berharap pada }} \\
{\text { pertolongan kepada Allah }} \\
{\text { c. Berharap berkah dan manfaat }} \\
{\text { dari ilmu yang dipelajari }}$ \\
\hline 7 & Tawakkal & Menanti hasil ujian & $\begin{array}{l}\text { a. Penyerahan diri kepada Allah } \\
\text { setelah berusaha } \\
\text { b. Kesiapan jiwa menerima hasil } \\
\text { usaha } \\
\text { c. Prasangka baik kepada Allah }\end{array}$ \\
\hline 8 & Taushiyah & Lapangan \& Aula/ Jumat \& Ramadan & a. Nilai rasa ingin tahu \\
\hline 9 & Tablig Akbar & Menjelang Ujian Nasional & b. Penambahan ilmu dan \\
\hline 10 & Tarbiyah & Masjid/ tiap hari Kamis & $\begin{array}{l}\text { wawasan keislaman } \\
\text { c. Sarana peningkatan iman } \\
\text { d. Sarana membicarakan masalah } \\
\text { keummatan. }\end{array}$ \\
\hline
\end{tabular}
\end{tabular}

Sumber: Hasil Wawancara dan Observasi Peneliti

b. Pembiasaan syukur

Sikap syukur juga menjadi perhatian besar bagi para Stakeholders SMA Negeri 10 Bulukumba, karena selain sebagai kewajiban seorang manusia terhadap Tuhannya, syukur juga menjadi salah satu amanah Kurikulum 2013 sebagai sikap spiritual yang harus ditanamkan dan ditumbuhkan pada peserta didik. Bapak Hamsa selaku Wakasek bagian kurikulum menuturkan bahwa dalam menanamkan dan menumbuhkan sikap syukur kepada para peserta didik terlebih dahulu kami juga para guru dan wakasek memberi teladan dalam menunjukkan rasa syukur itu, baik lisan maupun tulisan. Adapun secara lisan pada setiap momen dan kegiatan baik sesama guru dalam rapat atau bersama para peserta didik dalam upacara selalu memulai pembicaraan dengan memanjatkan puji syukur. Adapun secara tertulis setiap dokumen sekolah termasuk dokumen pembelajaran misalnya RPP sehingga setiap tenaga pendidik wajib mengucapkan rasa syukur sebelum menyampaikan materi pelajaran demikian pula setelah selesai menyampaikan pelajaran. ${ }^{33}$ Ibu Rosnaeni dalam wawancara menjelaskan bahwa menanamkan rasa syukur

\footnotetext{
${ }^{33}$ Hamsa, S.Pd., M.Pd, Wakil Kepala Sekolah Bagian Kurikulum, Wawancara, Bontobangun 15 Juni 2017.
} 
kepada para peserta didik sangat penting agar dapat tercermin dalam kehidupan rumah tangganya karena ketika ada diantara keluarganya (orang tua) misalnya yang memberi namun mereka tidak berterima kasih maka akan difonis sebagai anak yang tidak pandai mensyukuri pemberian. Lebih lanjut beliau menjelaskan bahwa syukur tidak hanya di mulut saja, dengan mengucapakan kata "alhamdulillah" namun harus diakui terlebih dahulu dalam hati bahwa nikmat dan kebaikan yang diraihnya adalah dari Allah lalu diucapkan di lisan dengan menceritakan nikmatnya sebagaimana perintah Allah dalam QS al-Ḍuhā/93: 11

$$
\text { وَأَمَّا بنِعْمَة رَبِّكَ فَحَدِّتْ }
$$

Terjemahnya:

"Dan terhadap ni'mat Tuhanmu maka hendaklah kamu menyebut-nyebutnya (dengan bersyukur). ${ }^{34}$

Lalu nikmat tersebut dimanfaatkan untuk beribadah dan ketaatan kepada Allah sebagai dzat yang telah mengaruniakan nikmat tersebut. Satu hal yang ibu Rosnaeni tekankan bahwa ketika mengucapkan "alhamdulillah" secara lisan agar mengikhlaskaan diri dan berhati-hati dengan riya atau sum'ah ketika ada orang lain yang mendengarkannya. Selain itu pengurus OSIS juga telah memasang pesan-pesan moral tentang syukur. ${ }^{35}$ Kebiasaan syukur yang ditumbuhkembangkan di SMA Negeri 10 Bulukumba dapat peneliti klasifikasikan pada tabel berikut ini:

Tabel 0.2. Klasifikasi bentuk syukur

\begin{tabular}{|c|l|l|l|}
\hline No & \multicolumn{1}{|c|}{ Bentuk Syukur } & \multicolumn{1}{|c|}{ Keterangan } & \multicolumn{1}{|c|}{ Nilai Pend. Islam } \\
\hline 1 & Syukur dalam hati & $\begin{array}{l}\text { Mengakui bahwa nikmat dari } \\
\text { Allah }\end{array}$ & $\begin{array}{l}\text { a. Nilai tawadu } \\
\text { b. Nilai harapan dapat } \\
\text { tambahan nikmat }\end{array}$ \\
\hline 2 & Syukur pada lisan & Mengucapkan puji-pujian & $\begin{array}{l}\text { a. Nilai pengagungan } \\
\text { b. Nilai penghargaan }\end{array}$ \\
\hline 3 & Syukur pd perbuatan & Dengan melakukan ibadah & $\begin{array}{l}\text { a. Nilai semangat } \\
\text { beribadah }\end{array}$ \\
\hline
\end{tabular}

\footnotetext{
${ }^{34}$ Kementrian Agama RI, Al-Qura'n dan Terjemahnya (Cet. I; Jakarta: Syaamil Quran, 2015), h. 596.

${ }^{35}$ Rosnaeni, S.Pd.I, Guru PAI SMA Negeri 10 Bulukumba, wawancara, Bontobangun 08 Juni 2017.
} 


\begin{tabular}{|c|l|l|l|}
\hline 4 & Syukur memerima kebaikan & Diberi kemudahan oleh gurunya & $\begin{array}{l}\text { b. Nilai optimisme } \\
\text { b. Nilai kebijakan }\end{array}$ \\
\hline 5 & Syukur menerima pemberian & Diberi biaya oleh orang tua & $\begin{array}{l}\text { a. Nilai kasih sayang } \\
\text { b. Nilai perhatian } \\
\text { c. Nilai tanggungjawab }\end{array}$ \\
\hline 6 & Syukur dapat belajar & Bila guru hadir & $\begin{array}{l}\text { a. Nilai pemuliaan } \\
\text { terhadap orang } \\
\text { berilmu } \\
\text { b. Nilai } \\
\text { terhadap ilmu }\end{array}$ \\
\hline 7 & Syukur selesai belajar & Bila guru menyelesaikan pelajaran & $\begin{array}{l}\text { a. Nilai Pengharapan } \\
\text { ilmu bermanfaat } \\
\text { b. Nilai pengharapan } \\
\text { ilmu berberkah }\end{array}$ \\
\hline & Syukur mendapat keberhasilan & Naik kelas/ lulus UN & $\begin{array}{l}\text { a. Nilai rida menerima } \\
\text { keputusan Allah } \\
\text { b. Nilai menuai hasil }\end{array}$ \\
\hline
\end{tabular}

Sumber: Hasil Wawancara dan Observasi Peneliti

c. Pembiasaan jujur

Upaya menanamkan sikap jujur kepada peserta didik, Kepala sekolah dan para wakil kepala sekolah serta seluruh tenaga pendidik khususnya GPAI, Ibu A. Nirwati selaku kepala sekolah menjelaskan bahwa kunci utamanya adalah keteladanan, pihak kepala sekolah berupaya menampakkan kejujuran itu dengan menyesuaikan antara ucapan dengan perbuatan, janji dengan buktinya, dalam menyampaikan orasi atau pidato selaku kepala sekolah senantiasa menyampaikan fenomena-fenomena yang didaptkan dari keseharian sekolah, tanpa menambah atau mengurangi substansi masalah, namun memberi tanggapan agar dipetik pelajarannya bagi para tenaga pendidik dan peserta didik, menyusun laporan sesuai dengan apa yang telah dilaksanakan sebelumnya. Sebagai manusia biasa kepala sekolah juga menyadari akan 
kekurangan dalam implementasi perkataan dan janji, namun tetap berupaya menunaikan manakala apa yang dijanjikan belum terealisasi sesuai waktunya, contoh ketika kepala sekolah menjajikan kepada GPAI dana Taushiyah Ramadhan dikeesokan harinya namun karena tiba-tiba ada tugas yang harus dilaksanakan di Makassar maka setelah kembali barulah dana itu diberikan kepada GPAI yang sudah tidak sesuai lagi waktu yang dijanjikan. ${ }^{36}$

Rosnaeni menjelaskan bahwa sikap jujur itu ditanamkan pada proses belajar mengajar dengan cara petama; ketika peserta didik meminta izin ke toilet maka diingatkan untuk betulbetul ke toilet, baik untuk buang air kecil atau cuci muka karena mengantuk. Kedua; pada saat ulangan harian dan semester diingatkan agar tidak membuka buku, atau membuat dan membuka catatan, menyontek kepada temannya. Sikap jujur dapat diuji dengan kelakuan peserta didik dalam kesehariannya misalnya ketika ada peserta didik yang terlambat masuk sebelum gurunya masuk kelas, maka selaku guru menanyakan alasan keterlambatannya, kejujurannya dapat dilihat dari bagaimana dia berbicara dan menunjukkan ekspresi wajah dan mimiknya, sebagai GPAI berupaya mendahulukan husnu dzhon, dengan harapan bahwa bila ternyata peserta didik tersebut berdusta maka suatu saat dia akan menyadari kesalahannya. ${ }^{37}$ Hamsa menuturkan bahwa untuk menanamkan sikap jujur pada ujian yang diselenggarakan, para tenaga pendidik semakin optimis dengan adanya sistem ujian online, hal ini telah diterapkan di SMA Negeri 10 Bulukumba dengan mengadakan ujian nasional berbasis komputer demikian pula test masuk peserta didik baru semua ujian via online, dan ahli pembuat aplikasi ujian telah merancang sistem agar komputer yang digunakan tidak dapat membuka page/ folder lain, sehingga dapat meminimalisir kecurangan peserta didik ketika ujian sedang berlangsung. ${ }^{38}$

Kebiasaan jujur yang ditumbuhkembangkan di SMA Negeri 10 Bulukumba dapat peneliti klasifikasikan pada tabel berikut ini:

Tabel 0.3. Klasifikasi bentuk jujur

\begin{tabular}{|c|l|l|l|}
\hline No & \multicolumn{1}{|c|}{ Bentuk jujur } & \multicolumn{1}{|c|}{ Keterangan } & Nilai Pend. Islam \\
\hline 1 & Berkata jujur pada setiap ucapan & Mengungkapkan sesuai kenyataan & $\begin{array}{l}\text { a. Nilai komitmen } \\
\text { b. Nilai keberanian }\end{array}$ \\
\hline 2 & Minta izin & Ke WC, atau acara di luar sekolah & a. Nilai Penghormatan \\
\hline
\end{tabular}

${ }^{36}$ Dra. A. Nirwati, S.Pd., MM., M.Pd, Kepala Sekolah SMA Negeri 10 Bulukumba, Wawancara, Bontobangun 05 Juni 2017.

${ }^{37}$ Rosnaeni, S.Pd.I, Guru PAI SMA Negeri 10 Bulukumba, wawancara, Bontobangun 08 Juni 2017.

${ }^{38}$ Hamsa, S.Pd., M.Pd, Wakil Kepala Sekolah Bagian Kurikulum, Wawancara, Bontobangun 15 Juni 2017. 


\begin{tabular}{|c|l|l|l|}
\hline 3 & Mengungkapkan alasan kesalahan & Bila melanggar & b. Nilai kepercayaan \\
\hline 4 & Mengerjakan tugas harian & Tidak menyontek & $\begin{array}{c}\text { a. Nilai keberaniaan } \\
\text { menanggung } \\
\text { hukuman } \\
\text { b. Nilai tanggungjawab }\end{array}$ \\
\hline 5 & Mengerjakan ujian & Tidak membuka buku/ catatan & $\begin{array}{l}\text { a. Nilai } \text { Nilai Percaytabilitas } \\
\text { b. Nilai }\end{array}$ \\
& & & $\begin{array}{l}\text { Silai Menghormati } \\
\text { guru }\end{array}$ \\
\hline
\end{tabular}

\section{Sumber: Hasil Wawancara dan Observasi Peneliti}

d. Pembiasaan santun/ sopan

Upaya menanamkan sikap santun/ sopan kepada para peserta didik juga ditempuh dengan pembiasaan dan keteladanan dari setiap stakeholder sekolah mulai dari kepala sekolah dan para wakilnya sampai pada para tenaga pendidik. A. Nirwati selaku kepala sekolah menjelaskan bahwa kunci utamanya adalah keteladanan. Di sekolah kami menerapkan budaya saling menghormati dan menghargai, yang muda menghormati yang tua dan yang tua menghargai yang lebih muda. Pihak sekolah juga telah memasang pesan-pesan moral untuk membudayakan Lima S yaitu; Senyum, Salam, Sapa, Sopan dan Santun. ${ }^{39}$ Muslim menjelaskan bahwa sikap santun/ sopan itu diwujudkan dengan berkata yang baik sesuai dengan kebiasaan masyarakat, misalnya dengan mengucapkan kata "kita" pengganti dari kata "kamu", saya dalam menyapa peserta didik biasanya menggunakan kata "anda" dan menyertai kata "nak" setiap kali berbicara atau menyebut mereka. Bentuk kesantunan/ kesopanan yang lain disebutkan oleh Bapak Muslim bahwa ketika saya mendapati ada kelas yang tidak belajar, saya masuk memberi bimbingan karakter diantaranya adalah agar peserta didik menghormati gurunya dengan tidak duduk pada posisi yang lebih tinggi dari orang tua atau gurunya di sekolah. Keberkahan ilmu dari setiap peserta didik juga tergantung dari bagaimana mereka menghormati gurunya. ${ }^{40}$

\footnotetext{
${ }^{39}$ Dra. A. Nirwati, S.Pd., MM., M.Pd, Kepala Sekolah SMA Negeri 10 Bulukumba, Wawancara, Bontobangun 05 Juni 2017.

${ }^{40}$ Drs. Muslim, Wakil Kepala Sekolah Bagian Kesiswaan, Wawancara, Bontobangun 04 Juli 2017.
} 
Awaluddin Azis mengemukakan kebiasaan sopanpun diterapkan pada setiap kali peserta didik meminjam sarana sekolah dengan datang menghadap baik-baik, tidak serta merta mengambil barang seperti infokus tanpa izin, kadang mengajukan surat peminjaman barang ketika hendak digunakan pada acara-acara tertentu, dan dikembalikan sesuai waktu yang telah ditetapkan. ${ }^{41}$ Dalam observasi peneliti juga kerap menemukan bila ada peserta didik yang hendak meminta tanda tangan kepala sekolah maka pihak staft tata usaha menghimbau peserta didik tersebut untuk memakai stofmap folio atau business file sebagai bentuk penghormatan kepada kepala sekolah. Observasi peneliti juga menemukan penggunaan bawaan kata "ki" dan bukan "ko" ketika mengajak misalnya "kesiniki" (sopan) "kesiniko" (tidak sopan), demikian pula bawaan "ta" untuk menunjukkan kepemilikan orang bugis misalnya "pulpenta" (sopan) bukan "pulpennu" (tidak sopan kepada . Penggunaan kata "kak" untuk yang lebih tua dan "dek" untuk yang lebih muda.

Sebagai bentuk kesopanan kepada guru A. Nurul Fatimah menjelaskan bahwa peserta didik menyapa dan memanggil guru dengan panggilan penghormatan dengan tidak menyebut namanya secara langsung, bila dipanngil mengatakan "iyye pak” atau "iyye bu”, masuk ke dalam kelas sebelum bapak/ ibu guru masuk mengajar, mendengarkan apa yang dijelaskan oleh bapak/ ibu guru, tidak memotong pembicaraannya kecuali bila telah diizinkan, tidak mengadukan halhal yang kurang disenangi dari sikap atau kepribadian guru kepada orangtua atau orang luar sekolah. ${ }^{42}$ Kesopanan yang ditunjukkan oleh Nurul Fatimah telah dipupuknya dari rumah, karena dalam wawancara orang tuanya Bapak A. Akil menuturkan bahwa sepengetahuannya anaknya di rumah sopan kepada orang tuanya dan kepada siapa saja, dan memang saya menanamkan kepadanya bahwa kesopanan kepada sesama adalah hal yang paling utama, nilai seorang manusia dipandang dari kesopanannya, tidak ada nilai manusia bila tidak memiliki kesopanan. ${ }^{43}$

Hasil implementasi nilai-nilai pendidikan pendidikan Islam (Ibadah, syukur, jujur dan santun/ sopan) pada peserta didik di SMA Negeri 10 Bulukumba dituangkan pada nilai rapor aspek sikap peserta didik dengan menerima seluruh penilaian guru bidang studi tentang sikap afektifnya. Sistem penilaian Kurikulum 2013 (K13) dengan mengunakan aplikasi E-Raport,

${ }^{41}$ Awaluddin Azis, S.Pd., Wakil Kepala Sekolah Bagian Sarana dan Prasarana, Wawancara, Bontobangun 08 Juni 2017.

${ }^{42}$ A. Nurul Fatimah, Peserta Didik Kelas X IPS 4 SMA Negeri 10 Bulukumba, Wawancara, Bontobangun 23 Mei 2017.

${ }^{43}$ A. Muhammad Akil, Orang Tua A. Nurul Fatimah Peserta Didik SMA Negeri 10 Bulukumba, Wawancara, Bontobangun 15 Juli 2017. 
(direct) penilaian langsung dari aplikasi, sehinggal hal tersebut mempermudah guru dalam memberikan penilaian, jadi ketika ada peserta didik yang menonjol dari segi sikap maka guru cukup mengetik kolom aspek sikap yang dianggap menonjol. Begitupun sebaliknya jika ada peserta didik yang kurang dari segi sikapnya maka guru hanya mengetik kolom sikap yang perlu diperbaiki dengan keterangan menunjukkan peningkatan. Kaitannya dalam penelitian ini adalah penilaian sikap guru bidang studi yang kemudian disimpulkan oleh wali kelas.

Hasil analisis data menunjukkan bahwa pada umumnya implementasi nilai-nilai pendidikan Islam (Ibadah, syukur, jujur, santun/ sopan) pada peserta didik melalui pembiasaan dan keteladanan dari Kepala sekolah dan para wakil kepala sekolah serta tenaga pendidik bidang studi PAI di SMA Negeri 10 Bulukumba telah menunjukkan keberhasilan. Karena setiap penilaian aspek sikap peserta didik (Ibadah, syukur, jujur, santun/ sopan) dominan menunjukkan kepada hasil yang baik.

Kebiasaan santun/ sopan yang ditumbuhkembangkan di SMA Negeri 10 Bulukumba dapat peneliti klasifikasikan pada tabel berikut ini:

Tabel 0.4. Klasifikasi bentuk santun/ sopan

\begin{tabular}{|c|c|c|c|}
\hline No & $\begin{array}{c}\text { Bentuk santun/ } \\
\text { sopan }\end{array}$ & Keterangan & Nilai Pend. Islam \\
\hline 1 & $\begin{array}{l}\text { Menghormati yang } \\
\text { lebih tua }\end{array}$ & Siswa kepada guru & $\begin{array}{l}\text { a. Penghormatan kpd org berilmu } \\
\text { b. Kerendahan hati }\end{array}$ \\
\hline 2 & $\begin{array}{l}\text { Menghargai yang } \\
\text { lebih muda }\end{array}$ & Guru kepada siswa & $\begin{array}{l}\text { a. Penghormatan kpd penuntut ilmu } \\
\text { b. Kerendahan hati } \\
\text { c. Keteladanan }\end{array}$ \\
\hline 3 & Sapaan "nak" & Sapaan guru kepada siswa & \multirow{6}{*}{$\begin{array}{l}\text { a. Nilai komunikatif/ bersahabat } \\
\text { b. Karakter cinta damai } \\
\text { c. Kasih sayang sesama } \\
\text { d. Kekeluargaan } \\
\text { e. Rendah hati }\end{array}$} \\
\hline 4 & Sapaan "iyye" & Bila mengiyakan & \\
\hline 5 & Sapaan "ki" & Menyuruh "ambilmiki" & \\
\hline 6 & Sapaan "ta" & $\begin{array}{l}\text { Menunjukkan kepunyaan } \\
\text { "pulpenta" }\end{array}$ & \\
\hline 7 & Sapaan "kak" & Senior kelas kepada junior & \\
\hline 8 & Sapaan "dek" & $\begin{array}{l}\text { Junior kelas kepada } \\
\text { seniornya }\end{array}$ & \\
\hline
\end{tabular}




\begin{tabular}{|l|l|l|l|}
\hline 9 & Sapaan "Tabe" & $\begin{array}{l}\text { Memohon izin/ permisi } \\
\text { sebelum berkata/ bertindak }\end{array}$ & \\
\hline
\end{tabular}

Sumber: Hasil Wawancara dan Observasi Peneliti

\section{PENUTUP}

Pembiasaan dan keteladanan adalah kunci keberhasilan penanaman nilai-nilai pendidikan Islam pada implementasi Kurikulum 2013 di SMA Negeri 10 Bulukumba yang didasarkan pada penanaman afektif yang terdiri dari sikap spiritual dan sikap sosial. Sikap spiritual seperti pembiasaan dan keteladanan ibadah berupa ibadah hati, lisan, maupun anggota badan. Pembiasaan tersebut menumbuhkan nilai ketundukan kepada Allah, jiwa dan raga senantiasa dekat kepada Allah. Pembiasaan dan keteladanan syukur berupa ucapan dan ajakan syukur baik lisan, tulisan, maupun perbuatan. Pembiasaan syukur menumbuhkan sikap kerendahan hati kepada Allah, harapan, dan semangat ibadah. Adapun sikap sosial terdiri atas sikap jujur berupa kesesuaian perkataan maupun perbuatan dengan kenyataan. Pembiasaan tersebut menumbuhkan nilai komitmen, keberanian dan tangung jawab. Sikap santun/ sopan terwujud dengan kebiasaan menghormati yang tua dan menghargai yang muda, penggunaan sapaan sesuai budaya bugis. Pembiasaan tersebut menumbuhkan karakter komunikatif dan cinta damai. Sikap spiritual, bertujuan membentuk karakter religius peserta didik yang beriman dan bertakwa, dan kompetensi sikap sosial, bertujuan membentuk peserta didik yang berkarakter jujur, komunikatif, cinta damai, dan bertanggung jawab. 


\section{DAFTAR PUSTAKA}

Al-Qura'n dan Terjemahnya, Kementrian Agama RI. Cet. I; Jakarta: Syaamil Quran, 2015.

Al-Bukhāri, Muhammad bin Ismāīl, Al-Jāmi' al-Ṣaḥ̄ḥ al-Mukhtaṣar, Juz 6. Beirut: Dār ibnu Kașīr, 1407 H/ 1987 M.

Al-Ḥaq, Abū 'Abdi al-Raḥmān Syarf. 'Aun al-Ma'būd Syarh Sunan Abī Dāwūd, Juz 2. Saudi; Bait al-Afkār al-Dauliyyah, 2013.

Al-Ṣābūn̄̄, Muḥammad 'Alī. Rawā'i' al-Bayān : Tafsīr Āyāt al-Aḥkām al-Qurān Juz 2. Cet. III; Beirut: Muassasah Manāhil al-'Irfān, 1981 M/1401 H.

Aly, Hery Noer. Ilmu Pendidikan Islam. Cet. II; Jakarta: PT Logos Wacana Ilmu, 1999 M/1420 $\mathrm{H}$.

Dāwud, Sulaimān Abū. Sunan Ab̄̄ Dāwud, Juz 14. Mesir: Mauqi' Wizārah al-Auqāf alMiśriyyah.

Farid, Ahmad. Pendidikan Berbasis Metode Ahlus Sunnah wa al-Jama'ah, Cet. I; Surabaya: Pustaka Elba, 2011.

Poerwati, Loeloek Endang dan Sofan Amri. Panduan Memahami Kurikulum 2013. Cet. I; Prestasi Pustaka: 2014.

Quțub, Muhammad, Manhaj al-Tarbiyyah al-Islāmiyyah Juz 1. Cet. XIV; Al-Qāhirah; Dār alSyurūq, 1993 M/ 1414 H.

------. Manhaj al-Tarbiyyah al-Islāmiyyah (Sistem Pendidikan Islam) terj. Salman Harun. Bandung; Al-Maarif, 1984.

'Ulwān, Abdullāh. Tarbiyyah al-Aulād fì al-Islām, Juz 2. Beirut;Dār al-Salām, 1978.

Zakiyah, Qiqi Yuliati dan A. Rusdiana. Pendidikan Nilai, Kajian Teori dan Praktik di Sekolah. Cet. I; Bandung: Pustaka Setia, 2014.

http://www.sman10bulukumba.sch.id/profile/visi-dan-misi 